\title{
Relationship of Conformity with Adolescent Impulsion Buying Behavior on Fashion Products in Marketplace with Self-Control as a Moderating Variable
}

\author{
Egi Vizya Adri ${ }^{1}$, Dedi Setiawan ${ }^{2}$ Okuard Methindo ${ }^{3}$ \\ Universitas Persada Indonesia YAI Central Jakarta, Indonesia ${ }^{\mathrm{I}, 2,3}$ \\ egivizyaadri@gmail.com dedisetiawan.an@gmail.com² Okuardmethindo@gmail.com³
}

\begin{abstract}
The aim of this study is to determine the effect of conformity on adolescent impulsive buying behavior on fashion products in the marketplace moderated by self-control. The research method used in this research is quantitative. The data collection used in this research is by sharing the questionnaire in the form of Google Form starts from July to September. The researchers use non-probability sampling method with voluntary response sampling. Respondents in this study are 150 teenagers. The data analysis technique used in this research is multiple linear regression analysis. Based on the results of data analysis carried out, it is found that there is a significant relationship between conformity to adolescent impulsive buying behavior. Furthermore, the self-control variable as a moderating variable also has a significant effect on the independent and dependent variables in this study. The results of the study found that the conformity variable $(\mathrm{X})$ simultaneously affected the impulsive buying variable (Y) by $73.1 \%$, while $26.9 \%$ is influenced by other variables outside the regression equation or variables that are not examined. Other than that, the self-control as the moderation variable can moderate the effect between conformity and impulse buying in adolescents. For further research, there needs other variables that can be conducted to know what affects impulse buying with conducting to other types of society other than an adolescent.
\end{abstract}

Keywords: conformity, impulse buying, fashion products, marketplace, self-control

\begin{abstract}
Abstrak
Penelitian ini bertujuan untuk menguji pengaruh konformitas terhadap perilaku pembelian impulsif remaja pada produk fashion di marketplace yang dimoderatori oleh pengendalian diri. Metode yang digunakan dalam penelitian ini adalah kuantitatif. Pengumpulan data yang digunakan adalah dengan menyebarkan kuesioner dalam bentuk google form pada bulan Juli sampai September. Peneliti menggunakan metode non-probability sampling dengan voluntary response sampling. Responden dalam penelitian ini adalah 150 remaja. Teknik analisis data yang digunakan dalam penelitian ini adalah analisis regresi linier berganda. Berdasarkan hasil analisis data yang dilakukan, ditemukan adanya hubungan yang signifikan antara konformitas dengan perilaku pembelian impulsif remaja. Selanjutnya variabel pengendalian diri sebagai variabel moderasi juga berpengaruh signifikan terhadap variabel bebas dan terikat dalam penelitian ini. Hasil penelitian menemukan bahwa variabel konformitas (X) secara simultan berpengaruh terhadap variabel pembelian impulsif (Y) sebesar 73,1\%, sedangkan 26,9\% dipengaruhi oleh variabel lain di luar persamaan regresi atau variabel yang tidak diteliti. Selain itu, kontrol diri sebagai variabel moderasi dapat memoderasi pengaruh antara konformitas dan pembelian impulsif pada remaja. Untuk penelitian lebih lanjut, perlu adanya variabel lain yang dapat dilakukan untuk mengetahui apa yang mempengaruhi pembelian impulsif dengan melakukan untuk jenis masyarakat lain selain remaja.
\end{abstract}

Kata Kunci: konformitas, pembelian impulsif, produk fesyen, pasar, pengendalian diri. 


\section{Introduction}

Globalization is a mass integration of humans from various aspects, both in the form of products, thoughts, and culture. This is marked by the increasingly sophisticated transportation and telecommunications, as well as the emergence of the internet which makes humans experience economic and cultural dependence on each other (Idayanti et al., 2019). Advances in sophisticated smartphone technology with various applications, such as social applications, buying and selling online, and the education sector are also used as modern industrialization (Liu et al., 2017). The internet as a form of communication media has experienced rapid development currently (Elvinawanty et al., 2020). Based on the Geographic Regions in 2018, the most internet users in the world are in Asia, which is $2,062,197,366$ users. From several countries in Asia that use the internet, Indonesia ranks third out of the number of users in Asia which is 132.7 million users (Arifianti, Ria \& Gunawan, 2020).

According to the facts and data regarding the rapid development of digital media having an impact on changes in the media landscape, it encourages changes in views, concepts, and orientations in other fields including business and marketing fields (Sarrascalao, 2019). In a journal on internet marketing written by Ayuni et al., (2019), it is stated that, in the marketing field, a new view and concept of modern market/consumer-oriented marketing emerges in the form of an electronic marketplace. In the past, there was a traditional face-to-face business interaction model, but currently, the interaction model has developed towards a modern electronic-based interaction or e-commerce (Irma et al., 2016). One form of business and marketing activity that applies the concepts of the electronic marketplace, digital marketing, and e-commerce currently rampant is an online shop business or online shopping site (Mardhiah \& Lutfi, 2019). The fact is that not all consumers act rationally and logically when making purchases online; this phenomenon is called impulse buying (Ittaqullah et al., 2020).

Impulse buying generally occurs without any prior preparation or planning spontaneously (Bellini et al., 2017). According to Thürmer et al. (2020), impulse buying is generally a buying process that is not based on a purchase plan and usually occurs when the impulse or stimulus for wanting to own something is seen at that time. After making a purchase, consumers usually experience an emotional or cognitive reaction. According to Aldhmour and Sarayrah, (2016), a person's buying behavior will be influenced by various groups consisting of all groups that have a direct or indirect influence on a person's attitude or behavior. A group usually has an opinion leader that influences its members to make a purchase.

This happens mostly for teenagers or adolescents that sometimes are easy to use their money to buy something for their lifestyle. Li et al., (2018) mention that the characteristics of adolescent consumers, especially young women, are easy to ask friends for opinions and easily persuaded by their friends. Hjerm et al., (2020) stated that, in the social development of adolescents, an individual begins to separate themselves from their parents and towards their peers. Individuals want to be appreciated and want to show their existence causing teenagers to make impulse purchases where teenagers buy goods that are not in accordance with their needs but only to satisfy their desires.

The results of previous research conducted by Solikhah and Dhania, (2017) show that there is a positive relationship between conformity to peer groups and impulse buying. In line with this, Indah Haryani \& Jhon Herwanto (2014) state that there is a positive relationship between conformity to impulse buying. In addition, research from Solikhah and Dhania, (2017) shows that there is a significant positive effect between peer conformity and impulsive buying. Furthermore, research conducted by Rozaini \& Ginting (2019) states that self-control has a negative and significant relationship with impulse buying. Research conducted by Fauziyah \& Fatmawati (2018) shows that situational factors (shopping with family or friends) influence impulse buying decisions.

From the previous researches conducted before, there has not been any research that discusses the role of self-control as the moderation variable between conformity and impulse buying. It is important to know the role the self-control moderation variable whether it can avoid or not the conformity toward impulse buying, especially adolescent because it can be the parameter used to prevent excessive impulse buying. Based on the explanation above and the results of previous studies, the researchers are interested 
in examining the relationship between conformity and impulsive buying behavior of adolescents on fashion products in the marketplace with self-control as a moderating variable.

\section{Method}

The research method used in this study is a quantitative method. The quantitative research method is designed to test existing hypotheses (Apuke, 2017). Quantitative methods are expressed as numbers obtained from measurements using a variable scale in research. This quantitative research is used to understand and find the research result of the relationship between conformity and impulsive buying behavior of adolescents on fashion products in the marketplace with self-control as a moderating variable.

The data collection used in this research is by sharing the questionnaire in the form of google form starts from July to September. The researchers use a non-probability sampling method with voluntary response sampling. A voluntary response sample is mainly based on ease of access. Instead of the researcher choosing participants and directly contacting them, people volunteer themselves by responding to a public online survey. Therefore, the respondents in this study are 150 teenagers in Indonesia aged 13 to 17 who volunteered themselves to be the participants of this research.

The data analysis used a structural approach to the Structural Equation Model (SEM) assisted by the smart PLS application. The stages of data analysis in this study are defined as follows.

1. The measurement model stage. This stage is carried out to test the validity and reliability of each indicator. The validity test in this study uses convergent validity by correlating the item score (component score) with the construct score; then, it produces the loading factor value. The instrument is declared valid if it has a loading factor value of $>0.6$. After conducting the validity test, a reliability test is carried out to determine the reliability of the instrument. Measurement of the level of reliability in this study uses alpha coefficient or Cronbach alpha and composite reliability; the item is declared reliable if it has a coefficient value of $>0.6$.

2. Structural Model Test Stage. This stage is a hypothesis testing stage that aims to determine whether there is an influence between variables or a correlation between constructs measured using SmartPLS. Structural or inner model is measured by looking at the r-square which shows how much influence between variables in the model, then proceed with the estimation of the path coefficient obtained by the bootsrtapping procedure with a value that is considered significant if the $t$-statistics is greater than 1.96 , with a score of $p$-value is $<0.05$, while to see the direction of the effect, the Beta value coefficient is used.

The definition of the key terms and indicators of each variable is described in the following table.

Table 1

Definition and Indicators of Variables

\begin{tabular}{|c|c|c|c|}
\hline No & Variable & Definition & Indicator \\
\hline 1 & $\begin{array}{l}\text { Impulse Buying } \\
\text { (Averil, 1973) }\end{array}$ & $\begin{array}{l}\text { Impulse buying is defined as an } \\
\text { unplanned, sudden, and } \\
\text { spontaneous impulse to buy, } \\
\text { which is not careful in evaluating } \\
\text { the product and the consequences } \\
\text { of subsequent purchases after } \\
\text { (Aragoncillo and Orús, 2018). } \\
\text { Impulse buying if defined in } \\
\text { general is the purchase of any } \\
\text { product immediately (Yudiatantri } \\
\text { \& Nora, 2019). Meanwhile, Chan } \\
\text { et al. (2017) state that impulse }\end{array}$ & $\begin{array}{l}\text { 1. Not thinking and considering the } \\
\text { use of goods } \\
\text { 2. Not planning before buying goods } \\
\text { 3. Not comparing the desired } \\
\text { product with other products } \\
\text { 4. There is a feeling of pleasure and } \\
\text { satisfaction only for a moment } \\
\text { when you see or see after making } \\
\text { a purchase } \\
\text { 5. There is a strong inner urge to } \\
\text { shop immediately }\end{array}$ \\
\hline
\end{tabular}




\begin{tabular}{|c|c|c|c|}
\hline & & $\begin{array}{l}\text { buying is a buying decision made } \\
\text { by consumers on the spot after } \\
\text { seeing the goods. }\end{array}$ & $\begin{array}{l}\text { 6. There is an urge to shop because } \\
\text { you see goods in certain } \\
\text { conditions }\end{array}$ \\
\hline 2 & $\begin{array}{l}\text { Conformity } \\
\text { (Reisch et al., } \\
\text { 2021) }\end{array}$ & $\begin{array}{l}\text { Conformity is a type of social } \\
\text { influence in which individuals } \\
\text { change their attitudes and } \\
\text { behavior to conform existing } \\
\text { social norms (Sartika \& Yandri, } \\
\text { 2019). Meanwhile, according to } \\
\text { Golman et al., (2016), conformity } \\
\text { is a change in behavior or beliefs } \\
\text { as a result of real group pressure } \\
\text { or only based on imagination to } \\
\text { be in harmony with others. }\end{array}$ & $\begin{array}{l}\text { 1. Feelings of wanting to be close to } \\
\text { group members because they want } \\
\text { to get recognition from the group } \\
\text { 2. Recognition of the group because } \\
\text { they want to get close to the group } \\
\text { 3. Adjustment with group members } \\
\text { 4. Attention shown to the group } \\
\text { 5. Trust in group opinion } \\
\text { 6. Equality of opinion among group } \\
\text { members because there is } \\
\text { dependence on the group } \\
\text { 7. Individual compliance to take } \\
\text { action because of threats or } \\
\text { rewards from the group } \\
\text { 8. The willingness of students to take } \\
\text { action in accordance with group } \\
\text { expectations because of threats or } \\
\text { rewards from the group }\end{array}$ \\
\hline 3 & $\begin{array}{l}\text { Self-Control } \\
\text { (Averil, 1973) }\end{array}$ & $\begin{array}{l}\text { Self-control is a psychological } \\
\text { variable that includes the ability } \\
\text { to modify behavior, the } \\
\text { individual's ability to manage } \\
\text { unwanted information, and the } \\
\text { individual's ability to choose an } \\
\text { action based on what is believed. } \\
\text { Valikhani et al., (2019) divide the } \\
\text { types of self-control into three, } \\
\text { namely behavioral control, } \\
\text { cognitive control, and decision } \\
\text { control. }\end{array}$ & $\begin{array}{l}\text { 1. Ability to control the situation } \\
\text { 2. Ability to regulate stimulus } \\
\text { 3. Ability to consider circumstances } \\
\text { 4. Ability to assess the situation } \\
\text { 5. Ability to assess the situation } \\
\text { 6. Ability to choose actions }\end{array}$ \\
\hline
\end{tabular}

Before conducting a research, the hypothesis should be constructed. The hypothesis that exists in this research is stated in the following.

H1: There is an effect of conformity on impulsive buying behavior in adolescents

$\mathrm{H} 2$ : There is an effect of conformity on impulsive buying behavior in adolescents moderated by selfcontrol

\section{Results and Discussion}

\section{Validity Test}

Validity test serves to measure the validity of the questionnaire. In this study, if the value of r-count $>$ $\mathrm{r}$-table, the questionnaire item is declared valid. Meanwhile, if the value of $\mathrm{r}$ count $<\mathrm{r}$ table, the question item is declared invalid. 
Table 2

Validity Test Result

\begin{tabular}{llll}
\hline \multicolumn{1}{c}{ Indicator } & r-count & r-table & Result \\
\hline Conformity_1 & 0.658 & 0.1966 & Valid \\
\hline Conformity_2 & $0.517^{* *}$ & 0.1966 & Valid \\
\hline Conformity_3 & 0.647 & 0.1966 & Valid \\
\hline Conformity_4 & 0.636 & 0.1966 & Valid \\
\hline Conformity_5 & 0.597 & 0.1966 & Valid \\
\hline Conformity_6 & 0.417 & 0.1966 & Valid \\
\hline Conformity_7 & 0.688 & 0.1966 & Valid \\
\hline Conformity_8 & 0.549 & 0.1966 & Valid \\
\hline Behavior_Consumer 1 & 0.411 & 0.1966 & Valid \\
\hline Behavior_Consumer 2 & 0.527 & 0.1966 & Valid \\
\hline Behavior_Consumer 3 & 0.604 & 0.1966 & Valid \\
\hline Behavior_Consumer 4 & 0.534 & 0.1966 & Valid \\
\hline Behavior_Consumer 5 & 0.626 & 0.1966 & Valid \\
\hline
\end{tabular}

\section{Reliability Test}

In this study, researchers use two types of reliability tests, namely the Cronbach Alpha test and the Composite Reliability test. Cronbach Alpha measures the lowest value (lower-bound) reliability; the data is declared good if the data has a Cronbach alpha value of $>0.6$. Meanwhile, composite reliability measures the actual reliability value of a variable. The data is declared to have high reliability if it has a composite reliability score of $>0.7$

Table 3

Reliability Test Result

\begin{tabular}{llc}
\hline \multicolumn{1}{c}{ Variable } & Cronbach Alpha & Result \\
\hline Conformity (X) & 0.736 & Reliable \\
\hline Consumer Behavior (Y) & 0.601 & Reliable \\
\hline Self-Control (Z) & 0.816 & Reliable \\
\hline
\end{tabular}

Based on the calculations carried out, it is found that all items of the instrument are reliable with all variables having a Cronbach Alpha score of $>0.6$ and Composite Reliability of $>0.7$.

\section{Classic Assumption Test}

Normality test

In this study, if Sig. (Significance) or probability value of $>0.05$, the data is normally distributed. Meanwhile, if Sig. (Significance) or probability value of $<0.05$, the data is not normally distributed.

Table 4

Normality Test Result for $1 X$-Y Model

\begin{tabular}{llr}
\hline \multicolumn{3}{c}{ One-Sample Kolmogorov-Smirnov Test } \\
\hline & & \multicolumn{1}{c}{$\begin{array}{c}\text { Unstandardized } \\
\text { Residual }\end{array}$} \\
\hline $\mathbf{N}$ & & 100 \\
\hline Normal Parameters $^{\mathbf{a}, \mathbf{b}}$ & Mean & $0 \mathrm{E}-7$ \\
\cline { 2 - 3 } & Std. Deviation & .30328560 \\
\hline & Absolute & .061 \\
\hline
\end{tabular}




\begin{tabular}{llr}
\hline Most Extreme Differences & Positive & .033 \\
\cline { 2 - 3 } & Negative & -.061 \\
\hline Kolmogorov-Smirnov Z & & .612 \\
\hline Asymp. Sig. (2-tailed) & .848 \\
\hline a. Test distribution is Normal. & \\
\hline b. Calculated from data. & \\
\hline
\end{tabular}

In the calculation results above, it is known that the data is normally distributed.

Table 5

Normality Test Result for $2 X^{\star} Z-Y$ Model

\begin{tabular}{llr}
\hline \multicolumn{3}{c}{ One-Sample Kolmogorov-Smirnov Test } \\
\hline & & \multicolumn{1}{c}{$\begin{array}{c}\text { Unstandardized } \\
\text { Residual }\end{array}$} \\
\hline $\mathbf{N}$ & & 100 \\
\hline Normal Parameters ${ }^{\mathbf{a}, \mathbf{b}}$ & Mean & $0 \mathrm{E}-7$ \\
\cline { 2 - 3 } & Std. Deviation & .29647541 \\
\hline Most Extreme & Absolute & .065 \\
\cline { 2 - 3 } Differences & Positive & .055 \\
\cline { 2 - 3 } & Negative & -.065 \\
\hline Kolmogorov-Smirnov Z & & .652 \\
\hline Asymp. Sig. (2-tailed) & & .788 \\
\hline a. Test distribution is Normal. & \\
\hline b. Calculated from data. & \\
\hline
\end{tabular}

In the calculation results above, it is known that the data is normally distributed.

\section{Heteroscedasticity Test}

In this study, if the t-arithmetic value is $>t$-table and the significance value $<0.05$, heteroscedasticity occurs. Meanwhile, if the $\mathrm{t}$-arithmetic value is $<\mathrm{t}$-table and the significance value is $>0.05$, there is no heteroscedasticity.

Table 6

Heteroscedasticity Test Result

\begin{tabular}{|c|c|c|c|c|c|c|}
\hline \multicolumn{7}{|c|}{ Coefficients $^{\mathrm{a}}$} \\
\hline \multirow{2}{*}{\multicolumn{2}{|c|}{ Model }} & \multicolumn{2}{|c|}{$\begin{array}{l}\text { Unstandardized } \\
\text { Coefficients }\end{array}$} & \multirow{2}{*}{$\begin{array}{l}\text { Standardized } \\
\text { Coefficients } \\
\text { Beta }\end{array}$} & \multirow[t]{2}{*}{$\mathrm{t}$} & \multirow[t]{2}{*}{ Sig. } \\
\hline & & \multicolumn{2}{|r|}{ Error } & & & \\
\hline \multirow[t]{3}{*}{1} & (Constant) & .217 & .163 & & 1.328 & .187 \\
\hline & Conformity & .022 & .051 & .065 & .441 & .661 \\
\hline & Self-Control & -.019 & .059 & -.047 & -.323 & .747 \\
\hline
\end{tabular}

a. Dependent Variable: abs_RES

\section{Multicollinearity Test}

In this study, if the tolerance value is $>0.10$ and the VIF value is $<0.10$, it means that there is multicollinearity. Meanwhile, if the tolerance value is $<0.10$ and the VIF value is $>0.10$, it means that there is no multicollinearity. 
Table 7

Multicollinearity Test Result

\begin{tabular}{|c|c|c|c|c|c|c|c|c|}
\hline \multicolumn{9}{|c|}{ Coefficients $^{\mathrm{a}}$} \\
\hline \multirow{2}{*}{\multicolumn{2}{|c|}{ Model }} & \multicolumn{2}{|c|}{$\begin{array}{l}\text { Unstandardize } \\
\text { d Coefficients }\end{array}$} & \multirow{2}{*}{$\begin{array}{c}\text { Standardized } \\
\text { Coefficients }\end{array}$} & \multirow[t]{2}{*}{$\mathrm{t}$} & \multirow[t]{2}{*}{ Sig. } & \multicolumn{2}{|c|}{$\begin{array}{l}\text { Collinearity } \\
\text { Statistics }\end{array}$} \\
\hline & & $\mathrm{B}$ & $\begin{array}{l}\text { Std. } \\
\text { Error }\end{array}$ & & & & $\begin{array}{c}\text { Tolera } \\
\text { nce }\end{array}$ & VIF \\
\hline \multirow[t]{3}{*}{1} & (Constant) & 3.258 & .259 & & $\begin{array}{r}12.58 \\
3\end{array}$ & $\begin{array}{r}.00 \\
0\end{array}$ & & \\
\hline & Conformity & -.026 & .081 & -.045 & -.321 & $\begin{array}{r}.74 \\
9\end{array}$ & .478 & 2.094 \\
\hline & Self-Control & .200 & .094 & .300 & 2.123 & $\begin{array}{r}.03 \\
6\end{array}$ & .478 & 2.094 \\
\hline
\end{tabular}

\section{a. Dependent Variable: Buying_Behavior}

Based on the research above, it can be seen that there is multicollinearity.

\section{Hypothesis Testing}

\section{$X-Y$ test}

In this study, if the significance is $>0.05$, it means that the independent variable $(\mathrm{X})$ has no effect on the dependent variable $(Y)$. Meanwhile, if the significance is $<0.05$, it means that the independent variable $(\mathrm{X})$ affects the dependent variable $(\mathrm{Y})$.

Table 8

$X-Y$ Test

\begin{tabular}{lcccc}
\hline \multicolumn{4}{c}{ Model Summary } \\
\hline $\begin{array}{l}\text { Mode } \\
1\end{array}$ & $\mathrm{R}$ & $\mathrm{R}$ & $\begin{array}{c}\text { Adjusted R } \\
\text { Square }\end{array}$ & $\begin{array}{c}\text { Std. Error } \\
\text { Square } \\
\text { of the } \\
\text { Estimate }\end{array}$ \\
\hline $\mathbf{1}$ & $.848^{\mathrm{a}}$ & .719 & .716 & .16393 \\
\hline a. Predictors: (Constant), Conformity &
\end{tabular}

a. Predictors: (Constant), Conformity

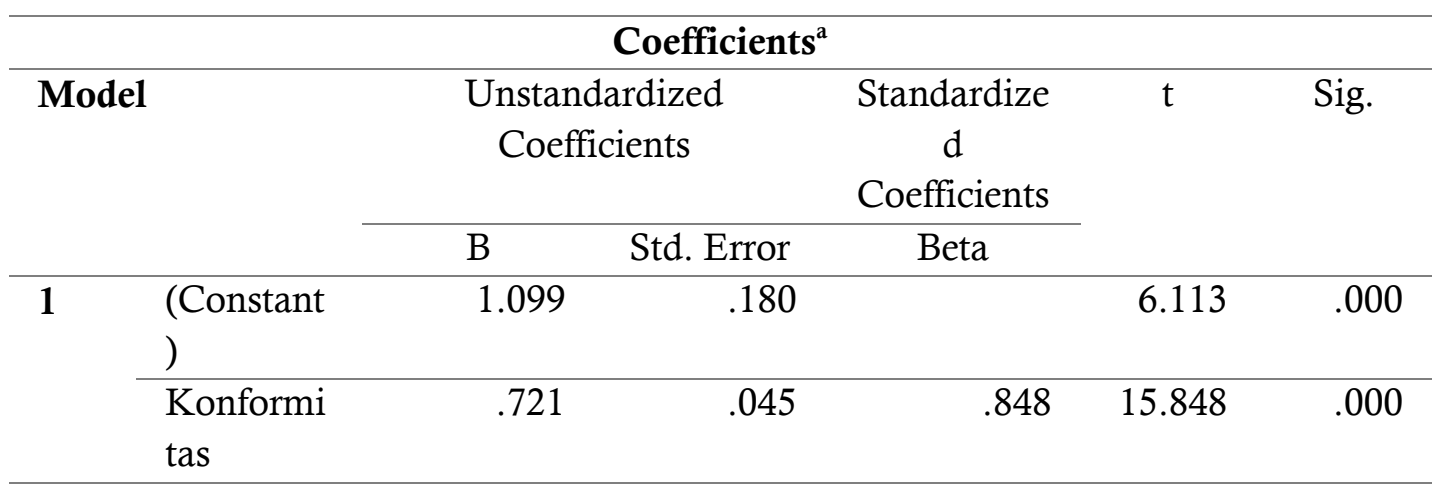

a. Dependent Variable: Selling_Behavior

From the results of the research above, it is known that the significance is 0.000 . Therefore, it can be said that the independent variable $(\mathrm{X})$ affects the dependent variable $(\mathrm{Y})$. 


\section{$X^{*} Z-Y$ Regression Test}

In this study, if the significance is $>0.05$, it means that the independent variable $(\mathrm{X})$ has no effect on the dependent variable $(\mathrm{Y})$. Meanwhile, if the significance is $<0.05$, it means that the independent variable $(\mathrm{X})$ affects the dependent variable $(\mathrm{Y})$.

Table 8

$X^{*} Z-Y$ Regression Test

\begin{tabular}{lcccc}
\hline \multicolumn{4}{c}{ Model Summary } \\
\hline Model & $\mathbf{R}$ & $\begin{array}{c}\mathbf{R} \\
\text { Square }\end{array}$ & $\begin{array}{c}\text { Adjusted R } \\
\text { Square }\end{array}$ & $\begin{array}{c}\text { Std. Error } \\
\text { of the } \\
\text { Estimate }\end{array}$ \\
\hline $\mathbf{1}$ & $.855^{\mathrm{a}}$ & .731 & .726 & .16128 \\
\hline \multicolumn{2}{l}{ a. Predictors: (Constant), INTERACTION, Conformity } \\
\hline
\end{tabular}

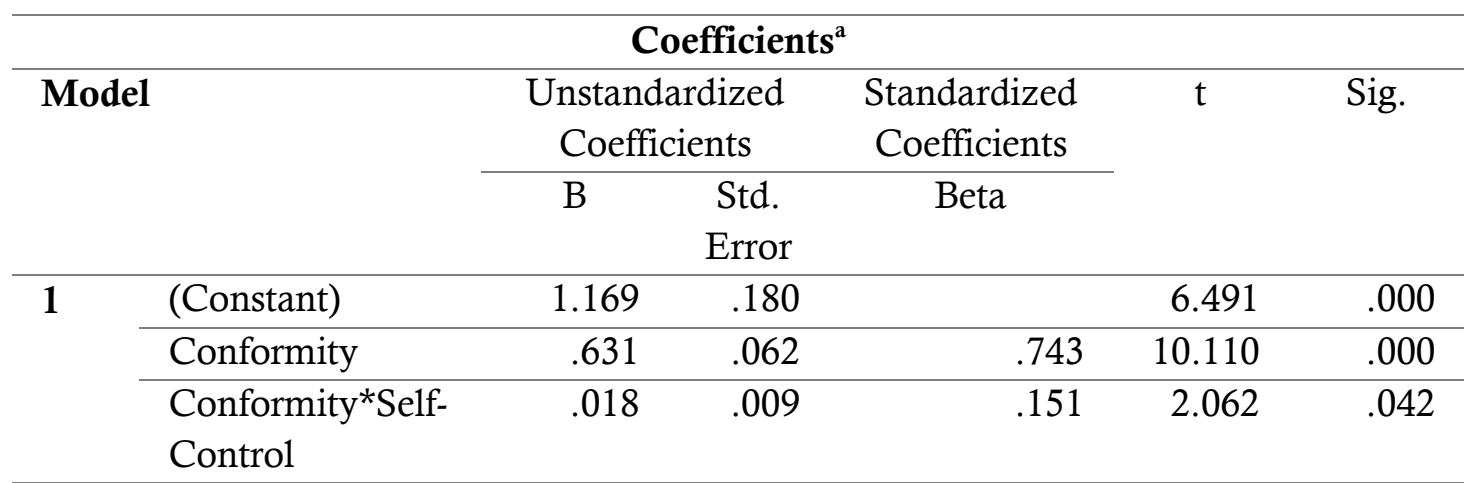

a. Dependent Variable: Selling_Behavior

From the results of the research above, it is known that the significance is 0.042 . Therefore, it can be said that the moderating variable $(\mathrm{Z})$ has an effect on the independent variable $(\mathrm{X})$ to the dependent variable $(\mathrm{Y})$.

\section{Discussion}

According to the test results that have been conducted, it is found that there is an effect between conformity on impulsive buying behavior in adolescents. It can be considered that this result accepts H1. It supports the research conducted by Bandyopadhyay, (2016) where there is a positive relationship between conformity to impulse buying. In addition, research from Cengiz, (2017) shows that there is a significant positive effect between peer conformity and impulse buying. The higher the conformity of peers, the higher the impulsive purchases made. Impulse buying behavior is becoming a trend among teenagers who are increasingly diverse to appear attractive and acceptable to their friends. The more positive the conformity to the peer group, the higher the impulsive buying in adolescents, conversely the more negative the conformity to the peer group, the lower the impulsive buying in adolescents.

Kornienko et al., (2016) state that there are four aspects of peer conformity. The first aspect is trust in the group, namely the individual's belief that all information provided by the group is true. The second aspect is weak trust in personal thoughts, namely individuals do not trust their abilities, resulting in individuals depending on groups. The third aspect is the fear of being a deviant, namely the individual's desire to be accepted and liked by the environment so that they do not look different from their social group. The fourth aspect is the fear of social reproach, namely the feeling of fear that an individual has when they are different from their group.

Self-control is one of the factors that can influence consumptive behavior. Togawa et al., (2020) state that good self-control individuals will refrain from making purchases that are spontaneous, only involve elements of excitement, and think less about the consequences after the purchase. Individuals who are 
not able to control themselves in making purchases can become impulsive buyers. The results of this study reject the results of research conducted by Iyer et al., (2020) which states that self-control has a negative and significant relationship with impulse buying.

Other than that, the research result shows that the self-control can moderate the effect between conformity and impulse buying. It can be concluded that this result accepts $\mathrm{H} 2$. It indicates that with selfcontrol, the intention of adolescents to do impulse buying when there is conformity can be decreased. Averill (in Braak et al., 2018) states that there are five aspects of self-control. The first aspect is behavioral control, namely the ability of individuals to control themselves and their behavior in certain situations so that they do not cause harmful behavior to themselves or others. The second aspect is cognitive control, namely the individual's ability to assess, interpret, and relate information to minimize the occurrence of deviant behavior or pressure. The third aspect is information control, namely the ability of individuals to obtain information or knowledge about unexpected events, the basis of events taking place, estimates of events occurring, and the consequences of these events that will be received by individuals. The fourth aspect is the control of past experiences (beliefs), namely the ability of individuals to process unexpected information by interpreting, assigning values, or integrating events with cognitive framework designs to reduce strong urges or pressure. The fifth aspect is decision control, namely the ability of individuals to choose an action based on what is believed or agreed upon.

\section{Conclusion}

According to the results of the research and discussion described, it can be concluded that there is a significant relationship between conformity to adolescent impulse buying on fashion products in the marketplace. Furthermore, the moderating variable in this study, the self-control variable, also has an effect on conformity to impulsive buying in adolescents. The results of the study found that the conformity variable (X) simultaneously affected the impulsive buying variable (Y) by $73.1 \%$ while $26.9 \%$ is influenced by other variables outside the regression equation or variables that are not examined in this research.

The limitation of this study is that the research is only conducted on adolescents and has only two variables with one moderation. For further research, there need other variables that can be conducted on know what affects impulse buying. In addition, the research conducted to other types of society other than adolescents is needed.

\section{References}

Aldhmour, F., \& Sarayrah, I. (2016). An investigation of factors influencing consumers' intention to use online shopping: An empirical study in south of Jordan. Journal of Internet Banking and Commerce.

Apuke, O. D. (2017). Quantitative research methods: a synopsis approach. Kuwait Chapter of Arabian Journal of Business and Management Review. https://doi.org/10.12816/0040336

Aragoncillo, L., \& Orús, C. (2018). Impulse buying behaviour: An online-offline comparative and the impact of social media. Spanish Journal of Marketing - ESIC. https://doi.org/10.1108/SJME03-2018-007

Arifianti, Ria \& Gunawan, W. (2020). Perilaku impulse buying dan interaksi sosial dalam pembelian di masa pandemi. SOSIOGLOBAL: Jurnal Pemikiran Dan Penelitian Sosiologi.

Ayuni, Q., Cangara, H., \& Arianto. (2019). Pengaruh Penggunaan Media Digital terhadap Tingkat Penjualan Produk Kuliner Kemasan. Jurnal Penelitian Komunikasi Dan Opini Publik.

Bandyopadhyay, N. (2016). The role of self-esteem, negative affect and normative influence in 
impulse buying: A study from India. Marketing Intelligence and Planning. https://doi.org/10.1108/MIP-02-2015-0037

Bellini, S., Cardinali, M. G., \& Grandi, B. (2017). A structural equation model of impulse buying behaviour in grocery retailing. Journal of Retailing and Consumer Services. https://doi.org/10.1016/j.jretconser.2017.02.001

Cengiz, H. (2017). Effect of the need for popularity on purchase decision involvement and impulsebuying behavior concerning fashion clothing. Journal of Global Fashion Marketing. https://doi.org/10.1080/20932685.2016.1257358

Chan, T. K. H., Cheung, C. M. K., \& Lee, Z. W. Y. (2017). The state of online impulse-buying research: A literature analysis. Information and Management. https://doi.org/10.1016/j.im.2016.06.001

Elvinawanty, R., Liza, W., Wong, J., Putri, Y., Citra, Y. C., \& Oktaviani, A. (2020). Intensi pembelian online ditinjau dari tipe kepribadian big five pada Mahasiswa Fakultas Psikologi Universitas Prima Indonesia Medan. TAZKIYA: Journal of Psychology. https://doi.org/10.15408/tazkiya.v8i1.14682

Fauziyah, F. A., \& Fatmawati, I. (2018). Pengaruh lingkungan toko terhadap keadaan emosional dan perilaku pembelian impulsif konsumen pengujian model mehrabian-russell. Jurnal Manajemen Dan Pemasaran Jasa. https://doi.org/10.25105/jmpj.v10i1.1852

Golman, R., Loewenstein, G., Moene, K. O., \& Zarri, L. (2016). The preference for belief consonance. Journal of Economic Perspectives. https://doi.org/10.1257/jep.30.3.165

Hjerm, M., Eger, M. A., Bohman, A., \& Fors Connolly, F. (2020). A New Approach to the Study of Tolerance: Conceptualizing and Measuring Acceptance, Respect, and Appreciation of Difference. Social Indicators Research. https://doi.org/10.1007/s11205-019-02176-y

Idayanti, S., Hartati, S., \& Haryadi, T. (2019). Pembangunan hukum bisnis dalam perspektif pancasila pada era revolusi industri 4.0. Jurnal Jurisprudence. https://doi.org/10.23917/jjr.v9i1.8091

Indah Haryani, \& Jhon Herwanto. (2014). Hubungan Konformitas dan Kontrol Diri Dengan Perilaku Konsumtif Terhadap Produk Kosmetik pada Mahasiswi. Jurnal Psikologi UIN Sultan Syarif Kasim Riau.

Irma, J., Chong, T., \& Ram, J. (2016). Empirically examining barriers to E-business adoption in SMES in Indonesia. Electronic Journal of Information Systems in Developing Countries. https://doi.org/10.1002/j.1681-4835.2016.tb00518.x

Ittaqullah, N., Madjid, R., \& Suleman, N. R. (2020). The effects of mobile marketing, discount, and lifestyle on consumers' impulse buying behavior in online marketplace. International Journal of Scientific and Technology Research.

Iyer, G. R., Blut, M., Xiao, S. H., \& Grewal, D. (2020). Impulse buying: a meta-analytic review. In Journal of the Academy of Marketing Science. https://doi.org/10.1007/s11747-019-00670-w

Kornienko, O., Santos, C. E., Martin, C. L., \& Granger, K. L. (2016). Peer influence on gender identity development in adolescence. Developmental Psychology. https://doi.org/10.1037/dev0000200 
Li, Q., Liang, N., \& Li, E. Y. (2018). Does friendship quality matter in social commerce? An experimental study of its effect on purchase intention. Electronic Commerce Research. https://doi.org/10.1007/s10660-018-9299-6

Liu, D., Bhagat, K. K., Gao, Y., Chang, T.-W., \& Huang, R. (2017). The Potentials and Trends of Virtual Reality in Education. https://doi.org/10.1007/978-981-10-5490-7_7

Mardhiah, D. R., \& Lutfi, I. (2019). Trust, Literasi Media, Kepribadian Hexaco dan Husnudzon Terhadap Kecenderungan Menggunakan Media Sosial. TAZKIYA: Journal of Psychology. https://doi.org/10.15408/tazkiya.v7i2.13479

Reisch, L. A., Sunstein, C. R., Andor, M. A., Doebbe, F. C., Meier, J., \& Haddaway, N. R. (2021). Mitigating climate change via food consumption and food waste: A systematic map of behavioral interventions. In Journal of Cleaner Production. https://doi.org/10.1016/j.jclepro.2020.123717

Rozaini, N., \& Ginting, B. A. (2019). Pengaruh literasi ekonomi dan kontrol diri terhadap perilaku pembelian impulsif untuk produk fashion. niagawan. https://doi.org/10.24114/niaga.v8i1.12795

Sarrascalao, D. D. (2019). Analisis Perilaku Impulse Buying dalam E-Commerce Perspektif Bisnis Syariah. Journal of Business \& Banking. https://doi.org/10.14414/jbb.v8i2.1645

Sartika, M., \& Yandri, H. (2019). Pengaruh layanan bimbingan kelompok terhadap konformitas teman sebaya. In Indonesian Journal of Counseling \& Development.

Solikhah, M., \& Dhania, D. R. (2017). Hubungan Antara Gaya Hidup Hedonisme dan Konformitas Teman Sebaya Dengan Perilaku Pembelian Impulsif Universitas Muria Kudus. Psikovidya.

ten Braak, D., Kleemans, T., Størksen, I., Verhoeven, L., \& Segers, E. (2018). Domain-specific effects of attentional and behavioral control in early literacy and numeracy development. Learning and Individual Differences. https://doi.org/10.1016/j.lindif.2018.10.001

Thürmer, J. L., Bieleke, M., Wieber, F., \& Gollwitzer, P. M. (2020). If-then plans help regulate automatic peer influence on impulse buying. European Journal of Marketing. https://doi.org/10.1108/EJM-05-2018-0341

Togawa, T., Ishii, H., Onzo, N., \& Roy, R. (2020). Effects of consumers' construal levels on postimpulse purchase emotions. Marketing Intelligence and Planning. https://doi.org/10.1108/MIP01-2019-0022

Valikhani, A., Goodarzi, M. A., \& Hashemi, R. (2019). Psychometric properties of dispositional selfregulation scale in iranian population and predicting inhibitory/initiatory self-control on the basis of it. Current Psychology. https://doi.org/10.1007/s12144-017-9574-z 